\title{
Prenatal imaging findings in fetal Zika virus infection
}

\author{
Edward Araujo Júnior ${ }^{\mathrm{a}}$, Francisco H.C. Carvalho ${ }^{\mathrm{b}}$, \\ Gabriele Tonni ${ }^{\mathrm{c}}$, and Heron Werner ${ }^{\mathrm{d}}$
}

\begin{abstract}
Purpose of review
The aim of this review is to report the most recent observations concerning intrauterine Zika virus (ZIKV) infection and associated neuroimaging.

Recent findings

ZIKV outbreak in Brazil in 2015 was associated with an impressive registration of cases of congenital microcephaly in women with symptoms suggestive of ZIKV infection. Clinical and laboratory testing for ZIKV and hypothetic etiopathogenetic mechanisms are described. Diagnostic tests on blood, urine and amniotic fluid should be performed in all mothers with symptoms suggestive of intrauterine ZIKV infection. ZIKV causes multiple teratogenic malformations, mainly affecting the developing brain.
\end{abstract}

\section{Summary}

Neuroimaging investigation contributes to the prenatal detection of microcephaly and other brain abnormalities in cases of intrauterine ZIKV infection. Neuroimaging is based antenatally on twodimensional and three-dimensional ultrasound and fetal MRI, whereas computed tomography scan is performed postnatally. Although neuropathology associated with intrauterine ZIKV infection is characterized by nonspecific findings of brain disorder, reduced cortical gyration and white-matter hypomyelination or dysmyelination and cerebellar hypoplasia have been consistently observed in the majority of fetuses and newborns. Prenatal or postnatal genetic workup should be carried out to exclude cases of primary microcephaly. Follow-up should rely upon MRI and computed tomography scan as well as neuropediatrician to better define developmental outcome in survivors.

\section{Keywords}

computed tomography, intrauterine infection, microcephaly, MRI, Zika virus

\section{INTRODUCTION}

One of the most outstanding viremia of the year 2000 may be the Zika virus (ZIKV) infection. There are data consistent with over 4 million people being infected in the Americas by ZIKV, although $80 \%$ of them are asymptomatic [1]. In adults, ZIKV infection is characterized by an erythematous rash and fever that may end, in the worse cases, in signs and symptoms overlapping with those of Guillan-Barrè syndrome. ZIKV was first isolated in a Uganda forest from a sentinel monkey (Macacamulata) in 1947 and has been active in several African and Asian countries as the first case of infection in humans through which ZIKV spread to the Pacific, especially to Yap Island [1] (Federated State of Micronesia) in 2007, French Polynesia (2008-2014) and more recently to the Americas. The infection is caused by a flavivirus and is related to dengue virus (DENV), chikungunya virus (CHIKV) and yellow fever. ZIKV has been isolated from Aedes africanus, Aedes luteocephalus, Aedes aegypti, Aedes albopictus, Aedes furcifer and Aedes vittatus mosquitoes, although $A$. aegypti is the main vector in the Brazilian outbreak [1-5].

When French Polynesia identified its first case in 2013 , it was further estimated that $11.5 \%$ (32 000) of

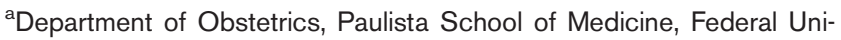
versity of São Paulo (EPM-UNIFESP), São Paulo, São Paulo, ${ }^{b}$ Department of Maternal and Child, Federal University of Ceará (UFC), Fortaleza, Ceará, Brazil, 'Department of Obstetrics and Gynecology, Guastalla Civil Hospital, AUSL, Reggio Emilia, Italy and dDepartment of Radiology, Clínica de Diagnóstico por Imagem (CDPI), Rio de Janeiro, Rio de Janeiro, Brazil

Correspondence to Prof Edward Araujo Júnior, PhD, Department of Obstetrics, Paulista School of Medicine, Federal University of São Paulo (EPM-UNIFESP), Rua Belchior de Azevedo, 156 apto. 111 Torre Vitoria, São Paulo CEP 05089-030, Brazil. Tel: +55 1137965944 ; fax: +55 11 37965944; e-mail: araujojred@terra.com.br
}

Curr Opin Obstet Gynecol 2017, 29:95-105

DOI:10.1097/GC0.0000000000000345 


\section{KEY POINTS}

- Main brain malformations in Zika virus intrauterine infection are the following: ventriculomegaly, brain calcifications, corpus callosum and cerebellar dysgenesis (mainly affecting the vermis), thalamic damage and severe brain atrophy leading to lissencephaly.

- Prenatal and postnatal neuroimaging in the case of Zika intrauterine infection is possible using twodimensional and three-dimensional ultrasound, computed tomography and MRI.

- Three-dimensional physical models from computed tomography and MRI scan data enhanced better reconstruction of brain abnormalities in Zika virus intrauterine infection.

the population had ZIKV-like symptoms. When the diagnostic test based on rRT-PCR (real-time reverse transcription-PCR) became available (2013-2014), surveillance found that 383 cases $(2.8 \%$ of the country's population) were serologically confirmed. At the time of ZIKV infection spreading in Yap in 2007, Duffy et al. [1] identified 185 cases of suspected ZIKV infections; a blood sample taken 10 days after the onset of symptoms resulted in 49 (26\%) confirmed and $59(32 \%)$ probable cases of ZIKV infection. The serologic test was based on an ELISA for IgM antibodies against ZIKV and DENV. The median age of patients with ZIKV infections was 36 years (range, $1-76)$ with $61 \%$ being women with sex-specific attack rates of 17.9 per 1000 women and 11.4 per 1000 men [1]. It may be estimated that between 500000 and 1.5 million of Brazilians were infected with ZIKV during the 2015 outbreak [6,7].

The autochthonous circulation of ZIKV in the Americas was first confirmed on Easter Island (Chile) in 2014 [8], whereas in Brazil the first laboratory confirmation was in mid-July $2015[9,10]$. The Brazilian Ministry of Health has estimated that between 440000 and 1300000 cases of ZIKV infections occurred in Brazil in the same year especially in the northeast state of Bahia (93\% of cases overall [11"] in which the attack rate has been calculated to range between 4.4 and 25 per 1000 inhabitants [12]). Notification of ZIKV cases is now conducted on behalf of the Brazilian health authority via the Notifiable Diseases Information System [13], with 22 out of 24 Brazilian administrative states registering autochthonous ZIKV infection [14].

ZIKV is a single stranded, icosahedral, positivesense RNA virus with a $10.7 \mathrm{~kb}$ genome encoding a single polyprotein that is cleaved into three structural proteins: capsid; precursor membrane/ membrane and E, envelope, and seven nonstructural proteins [15]. There are at present two main hypotheses according to which ZIKV would act. One is a direct viral effect in which glycoprotein $\mathrm{E}$ attaches to the cellular receptors of the host, followed by a process of endocytosis, viral fusion and virus release into the cytoplasm [16"']. The second may be secondary to a placental perturbation caused by ZIKV at the chorionic villi. ZIKV might cause the perturbed synthesis of neuropeptides and cytokines that are essential for normal fetal brain development [17]. It may be postulated that ZIKV accesses the embryo via placental macrophages that are more permissive than trophoblast cells to ZIKV [18"].

Laboratory confirmation of ZIKV infection relies on RT-PCR in blood, urine or both in symptomatic patients and in amniotic fluid in the case of congenital ZIKV infection [19",20"]. When suspected ZIKV infection is associated with microcephaly, cytomegalovirus, rubella virus, herpes simplex virus, DENV, CHIKV and toxoplasmosis must be investigated for cross-reactivity. In addition, anti-ZIKV antibodies are highly cross-reactive with other flaviviruses such as West Nile virus, Japanese encephalitis and yellow fever or induced from yellow fever and Japanese encephalitis vaccines [7].

Ultrasound and ultrasound-targeted f-MRI (fetal MRI) are diagnostic in the prenatal detection of brain abnormalities caused by ZIKV. The first publication of a possible association between a third trimester prenatal diagnosis (29.2 and 30.1 weeks' gestation, respectively) of microcephaly and ZIKV infection was reported by Oliveira Melo et al. [21"] in January 2016. Brain malformations were characterized by ventriculomegaly, brain calcifications, corpus callosum and cerebellar dysgenesis (mainly affecting the vermis), thalamic damage and severe brain atrophy leading to lissencephaly.

In this review, we present the main imaging prenatal diagnosis techniques for the assessment of the central nervous system (CNS) of fetuses affected by ZIKV intrauterine infection.

\section{TWO-DIMENSIONAL ULTRASOUND FINDINGS IN ZIKA VIRUS INTRAUTERINE INFECTION}

Following the initial suspicion of a link between ZIKV and fetal microcephaly, observations have emerged favoring evidence of this relationship, both in animal and human studies [19"-21"]. The neurotropism of the virus has been confirmed suggesting a role in all phases of neurodevelopment: proliferation, migration, organization and myelination $\left[22^{-\prime}, 23^{*}, 24^{-\prime}, 25^{*}, 26^{\prime \prime}\right]$. As a result, many other CNS disorders have been reported. Structural changes 
Table 1. Case reports describing two-dimensional ultrasound neuroimgaing findings in pregnancies with suspected/confirmed intrauterine Zika virus infection

\begin{tabular}{|c|c|c|c|c|c|}
\hline Author & $\begin{array}{l}\text { Clinical } \\
\text { symptoms }\end{array}$ & $\begin{array}{l}\text { Confirmed ZIKV } \\
\text { intrauterine infection }\end{array}$ & $\begin{array}{l}\text { Gestational age } \\
\text { at ultrasound }\end{array}$ & $\begin{array}{l}\text { Ultrasound } \\
\text { neuroimaging findings }\end{array}$ & $\begin{array}{l}\text { Extra-CNS } \\
\text { US findings }\end{array}$ \\
\hline $\begin{array}{l}\text { Oliveira Melo } \\
\quad \text { et al. [21"] }\end{array}$ & Not reported & $\begin{array}{l}\text { Yes - positive amniotic } \\
\quad \text { fluid }\end{array}$ & 30 weeks & $\begin{array}{l}\text { Microcephaly, calcifications } \\
\text { involving white matter of the } \\
\text { frontal lobe and cerebellum, } \\
\text { corpus callosum dysgenesis and } \\
\text { cerebellar vermis and } \\
\text { enlargement of the cisterna } \\
\text { magna }\end{array}$ & - \\
\hline
\end{tabular}

$\begin{array}{lll}\text { Case } 1 & \text { rRT-PCR } \\ \text { Oliveira Melo } & \text { Not reported } & \begin{array}{c}\text { Yes }- \text { positive amniotic } 29 \text { weeks } \\ \text { et al. [21"] }\end{array}\end{array}$
magna

\section{Microcephaly, severe unilateral} ventriculomegaly with midline deviation and thinning of the parenchyma, calcifications around the lateral ventricles and IVth ventricle, nonvisualization of the corpus callosum

\begin{tabular}{|c|c|c|c|}
\hline Case 2 & & rRT-PCR & \\
\hline $\begin{array}{c}\text { Mlakar et al. } \\
{\left[24^{=-1}\right]}\end{array}$ & Yes - 13 weeks & $\begin{array}{l}\text { Yes - rRT-PCR at } \\
\text { autopsy specimens }\end{array}$ & 32 weeks \\
\hline
\end{tabular}

\begin{tabular}{|c|c|c|c|c|c|}
\hline $\begin{array}{l}\text { Werner et al. } \\
\text { [27] }\end{array}$ & Yes - 10 weeks & $\begin{array}{l}\text { Yes - positive serology } \\
\text { at } 31 \text { weeks }\end{array}$ & 33 weeks & $\begin{array}{l}\text { Bilateral ventricular enlargement, } \\
\text { periventricular calcifications and } \\
\text { lissencephaly }\end{array}$ & $\begin{array}{l}\text { Abnormal profile } \\
\text { and nuchal } \\
\text { edema }\end{array}$ \\
\hline $\begin{array}{l}\text { Werner et al. } \\
\text { [28] }\end{array}$ & Yes - 12 weeks & No & 32 weeks & $\begin{array}{l}\text { Microcephaly and diffuse brain } \\
\text { calcifications }\end{array}$ & - \\
\hline \multirow[t]{2}{*}{$\begin{array}{l}\text { Calvet et al. } \\
\text { [19"] }\end{array}$} & Yes - 18 weeks & $\begin{array}{l}\text { Yes - positive } \\
\text { amniotic fluid }\end{array}$ & 21 weeks & $\begin{array}{l}\text { Microcephaly, ventricular } \\
\text { enlargement, cerebellar } \\
\text { hypoplasia and absence of } \\
\text { cerebellar vermis }\end{array}$ & - \\
\hline & & rRT-PCR & & & \\
\hline $\begin{array}{l}\text { Driggers et al. } \\
\text { [29] }\end{array}$ & Yes - 11 weeks & $\begin{array}{l}\text { Yes - positive rRT-PCR } \\
\text { in maternal serum }\end{array}$ & 19 weeks & $\begin{array}{l}\text { Thin cerebral cortex with increased } \\
\text { extra-axial space, dilation of the } \\
\text { third ventricle, enlargement of } \\
\text { both frontal horns and apparent } \\
\text { dysgenesis of the corpus callosum }\end{array}$ & - \\
\hline $\begin{array}{l}\text { Moron et al. } \\
\text { [30] }\end{array}$ & $\begin{array}{l}\text { Yes - 'Early in } \\
\text { the second } \\
\text { trimester' }\end{array}$ & $\begin{array}{l}\text { No - } \uparrow \lg G \text { positive but } \\
\text { lgM negative using } \\
\text { indirect ELISA assay. } \\
\text { rRT-PCR assay for } \\
\text { ZIKV in umbilical } \\
\text { cord blood was } \\
\text { negative }\end{array}$ & 32 weeks & $\begin{array}{l}\text { Microcephaly, brain cortical } \\
\text { atrophy, ventricular enlargement, } \\
\text { parenchymal calcifications, } \\
\text { lissencephaly and pachygyria, } \\
\text { increased subarachnoid space }\end{array}$ & $\begin{array}{l}\text { Redundant cranial } \\
\text { skin fold, } \\
\text { calcifications in } \\
\text { the placenta }\end{array}$ \\
\hline $\begin{array}{l}\text { Sarno et al. } \\
{\left[31^{-1}\right]}\end{array}$ & No & $\begin{array}{l}\text { Yes - positive rRT-PCR } \\
\text { at autopsy specimens } \\
\text { (brain, medulla } \\
\text { oblongata); positive } \\
\text { AF and in CSF }\end{array}$ & 21 weeks & $\begin{array}{l}\text { Severe microcephaly, } \\
\text { hydranencephaly, intracranial } \\
\text { calcifications and destructive } \\
\text { lesions of posterior fossa }\end{array}$ & $\begin{array}{l}\text { Hydrops } \\
\text { (hydrothorax, } \\
\text { ascites and } \\
\text { subcutaneous } \\
\text { edema) }\end{array}$ \\
\hline $\begin{array}{l}\text { Culjat et al. } \\
{\left[32^{-\prime}\right]}\end{array}$ & Not reported & $\begin{array}{l}\text { Yes - positive serum } \\
\operatorname{lgM} \text { and newborn } \\
\text { CSF }\end{array}$ & & $\begin{array}{l}\text { Diffuse parenchymal calcifications, } \\
\text { hydrocephalus ex vacuo and } \\
\text { cerebellar hypoplasia }\end{array}$ & - \\
\hline $\begin{array}{l}\text { Perez et al. } \\
{\left[3^{*}\right]}\end{array}$ & Yes - 17 weeks & $\begin{array}{l}\text { Yes - positive rRT-PCR } \\
\text { in maternal serum } \\
\text { and AF }\end{array}$ & 19 weeks & Bilateral hydrocephalus & $\begin{array}{l}\text { Arthrogryposis } \\
\text { multiplex } \\
\text { congenita }\end{array}$ \\
\hline
\end{tabular}

AF, amniotic fluid; CNS, central nervous system; CSF, cerebrospinal fluid; rRT-PCR, real-time reverse transcriptase-PCR; US, ultrasound; ZIKV, Zika virus.

beyond the CNS have also been reported. The frequency of microcephaly $[27,28]$ has been reported in only a few articles that described fetal findings in pregnancies that have been or were presumed to be affected by ZIKV $\left[20^{*}, 29,30\right]$. Tables 1 and 2 summarize the main ultrasonographic findings described in fetuses from pregnancies with confirmed or suspected ZIKV infection. 
Table 2. Case series describing two-dimensional ultrasound neuroimaging findings in pregnancies with suspected/confirmed Zika virus intrauterine infection

\begin{tabular}{|c|c|c|c|c|c|}
\hline Reference & $\begin{array}{l}\text { Size and sampling } \\
\text { characteristics }\end{array}$ & $\begin{array}{l}\text { Confirmed ZIKV } \\
\text { intrauterine infection }\end{array}$ & $\begin{array}{l}\text { Gestational } \\
\text { age at } \\
\text { ultrasound }\end{array}$ & $\begin{array}{l}\text { Ultrasound } \\
\text { neuroimaging findings }\end{array}$ & Extra CNS findings \\
\hline $\begin{array}{l}\text { Melo et al. } \\
\text { [34] }\end{array}$ & $\begin{array}{l}11 \text { cases of fetuses with } \\
\text { CNS changes at } \\
\text { ultrasound and confirmed } \\
\text { ZIKV. Clinical symptoms } \\
\text { suggestive of Flavivirus in } \\
90.1 \%\end{array}$ & $\begin{array}{l}\text { Yes - positive rRT-PCR in } \\
\text { amniotic fluid in } 6 \\
(54.5 \%) \text {. Other cases } \\
\text { confirmed with rRT-PCR } \\
\text { in newborn's CSF or in } \\
\text { autopsy specimens }\end{array}$ & 17-35 weeks & $\begin{array}{l}\text { Ventricular enlargement } \\
(90.1 \%) \text {, usually } \\
\text { asymmetric, severe } \\
\text { cerebral atrophy (81.8\%), } \\
\text { hypoplasia of the } \\
\text { cerebellar vermis and } \\
\text { cerebellum (81.8\%), } \\
\text { calcifications in the brain, } \\
\text { cerebellum and brainstem }\end{array}$ & $\begin{array}{l}\text { Fetal akinesia deformation } \\
\text { sequence or } \\
\text { arthrogryposis (27.3\%), } \\
\text { microphthalmia and } \\
\text { bilateral cataracts }(9.1 \%) \\
\text { and fetal growth restriction }\end{array}$ \\
\hline $\begin{array}{l}\text { Carvalho } \\
\text { et al. [20"] }\end{array}$ & $\begin{array}{l}19 \text { cases of microcephaly } \\
\text { (highly probable cases - } \\
\text { had specific neuroimaging } \\
\text { findings and negative } \\
\text { laboratory results for other } \\
\text { congenital infections). } \\
\text { Clinical symptoms } \\
\text { suggestive of Flavivirus in } \\
68.4 \%\end{array}$ & $\begin{array}{l}\text { Confirmed in } 2 \text { cases by } \\
\text { positive amniotic fluid } \\
\text { rRT-PCR }\end{array}$ & 22-39 weeks & $\begin{array}{l}\text { Cerebral calcifications } \\
(73.7 \%) \text {, unilateral or } \\
\text { bilateral ventricular } \\
\text { enlargement }(52.6 \%) \text {, } \\
\text { cerebellar calcifications } \\
(31.6 \%) \text {, increased } \\
\text { cisterna magna }(26.3 \%) \text {, } \\
\text { cerebellar vermis } \\
\text { dysgenesis/agenesis } \\
(15.8 \%) \text { and cerebral } \\
\text { atrophy/increased } \\
\text { subarachnoid space } \\
(15.8 \%)\end{array}$ & $\begin{array}{l}\text { Fetal growth restriction } \\
(26.3 \%) \text {, arthrogryposis/ } \\
\text { contractures }(15.8 \%) \text {, } \\
\text { olygohydramnios }(10.5 \%) \text {, } \\
\text { cardiac calcifications } \\
(5.3 \%) \text { and ocular } \\
\text { calcifications }(5.3 \%)\end{array}$ \\
\hline $\begin{array}{l}\text { Sarno et al. } \\
\text { [35] }\end{array}$ & $\begin{array}{l}52 \text { cases of microcephaly, } \\
\text { excluding other causes of } \\
\text { congenital infections. } \\
\text { Maternal exanthematic } \\
\text { disease was present in the } \\
\text { majority }(86.5 \%) \text { of cases, } \\
67.3 \% \text { in the first trimester } \\
\text { of pregnancy }\end{array}$ & $\begin{array}{l}\text { 78.3\% were classified as } \\
\text { confirmed cases } \\
\text { according to WHO } \\
\text { criteria for diagnosis } \\
\text { of ZIKV-related fetal } \\
\text { microcephaly }\end{array}$ & $19-40$ weeks & $\begin{array}{l}\text { Ventricular enlargement } \\
\text { (65.4\%), cerebral } \\
\text { periventricular/basal } \\
\text { ganglia calcifications } \\
(44.2 \%) \text {, posterior fossa } \\
\text { abnormalities }(32.7 \%) \text { and } \\
\text { corpus callosum } \\
\text { dysgenesis }(3.8 \%)\end{array}$ & $\begin{array}{l}\text { Fetal growth restriction } \\
(48.1 \%), \text { congenital } \\
\text { talipes }(17.3 \%), \\
\text { arthrogryposis }(9.6 \%), \\
\text { cardiac calcifications/ } \\
\text { pericardial effusion, } \\
(3.8 \%) \text {, olygohydramnios } \\
(11.5 \%) \text { and intrauterine } \\
\text { fetal death }(7.7 \%)\end{array}$ \\
\hline
\end{tabular}

CNS, central nervous system; CSF, cerebrospinal fluid; rRT-PCR, real-time reverse transcriptase-PCR; ZIKV, Zika virus.

The first prospective study was published by Brasil et al. [27] with 42 pregnant women from Rio de Janeiro, Brazil, who presented symptoms suggestive of ZIKV and were confirmed with rRTPCR between 6 and 35 weeks of gestation. There was fetal/placental impairment in 12 pregnancies (28.6\%). The main two-dimensional ultrasonographic findings described were microcephaly, cerebral and cerebellar calcifications, ventriculomegaly, brachycephaly cerebellar atrophy, agenesis vermis, mega cisterna magna, club foot, olygohydramnios/anhydramnios, fetal growth restriction, intrauterine fetal death and placental insufficiency as assessed by Doppler study. Four of the 12 (33.3\%) pregnancies presented Doppler changes. Doppler waveform abnormalities were reported in only one case out of $52(1.9 \%)$ in the series by Sarno et al. [30] and had not been previously seen by other authors, even in cases with associated fetal growth restriction. Microcephaly was still found in ZIKV infections occurring at 26 weeks. Only considering the ZIKV infections that occurred in the first trimester, the frequency of microcephaly was $22 \%$, much higher than the 1\% found in French Polynesia [28].

\section{THREE-DIMENSIONAL ULTRASOUND, MRI, COMPUTED TOMOGRAPHY AND THREE- DIMENSIONAL PHYSICAL MODEL FINDINGS IN ZIKA VIRUS INTRAUTERINE INFECTION}

ZIKV infection has been associated with several malformations of the CNS, especially microcephaly

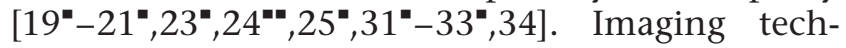
nology advancements have led to tremendous improvements in fetal evaluation. Two main technologies are mostly used to obtain images inside the uterus during pregnancy - ultrasound and MRI, whereas computed tomography (CT) scan is better performed postnatally. Ultrasound is currently the first method for fetal scanning as it is safer, patientfriendly, useful and cost-effective. When ultrasound provides equivocal results, f-MRI can be used to aid in diagnosis (Fig. 1). CT may also be performed but only after 30 weeks of gestation and in cases 


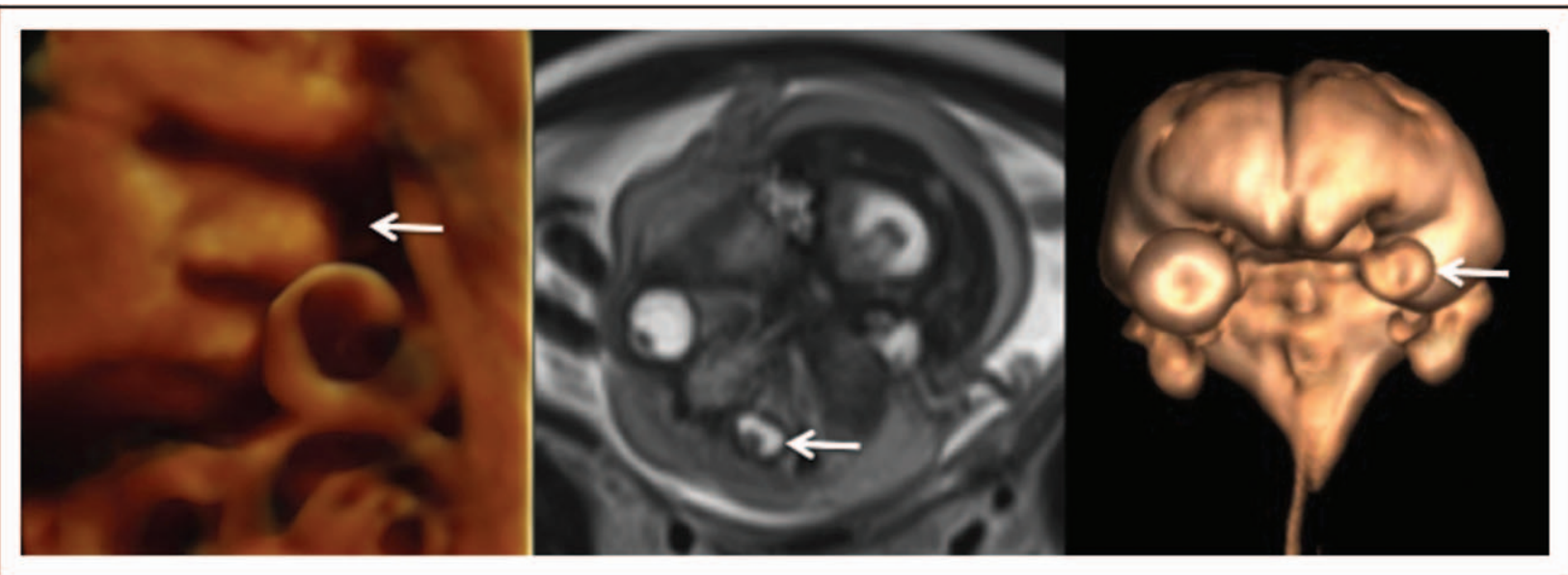

FIGURE 1. Three-dimensional ultrasound, MRI and three-dimensional reconstruction from MRI show unilateral microphthalmia (arrows) in a 37-week fetus with Zika virus infection. Note: the difficulty to see the microphthalmia in three-dimensional ultrasound due to fetal position.

associated with skeletal dysplasia [35]. As antenatal detection of microcephaly represents a complex and challenging case, combined investigations have been proposed to assist ultrasound diagnosis (Fig. 2) [32",36]. Three-dimensional ultrasound may not add important information in this particular setting. However, dedicated three-dimensional software has been developed to assist biometry obtained by real-time two-dimensional scanning, introducing fetal volume data sets. Although not all three-dimensional volume data sets are appropriate for further offline extraction of measurements, especially when the fetal head is in the anteroposterior position, good agreement between the two techniques was observed, even if threedimensional ultrasound was more time consuming

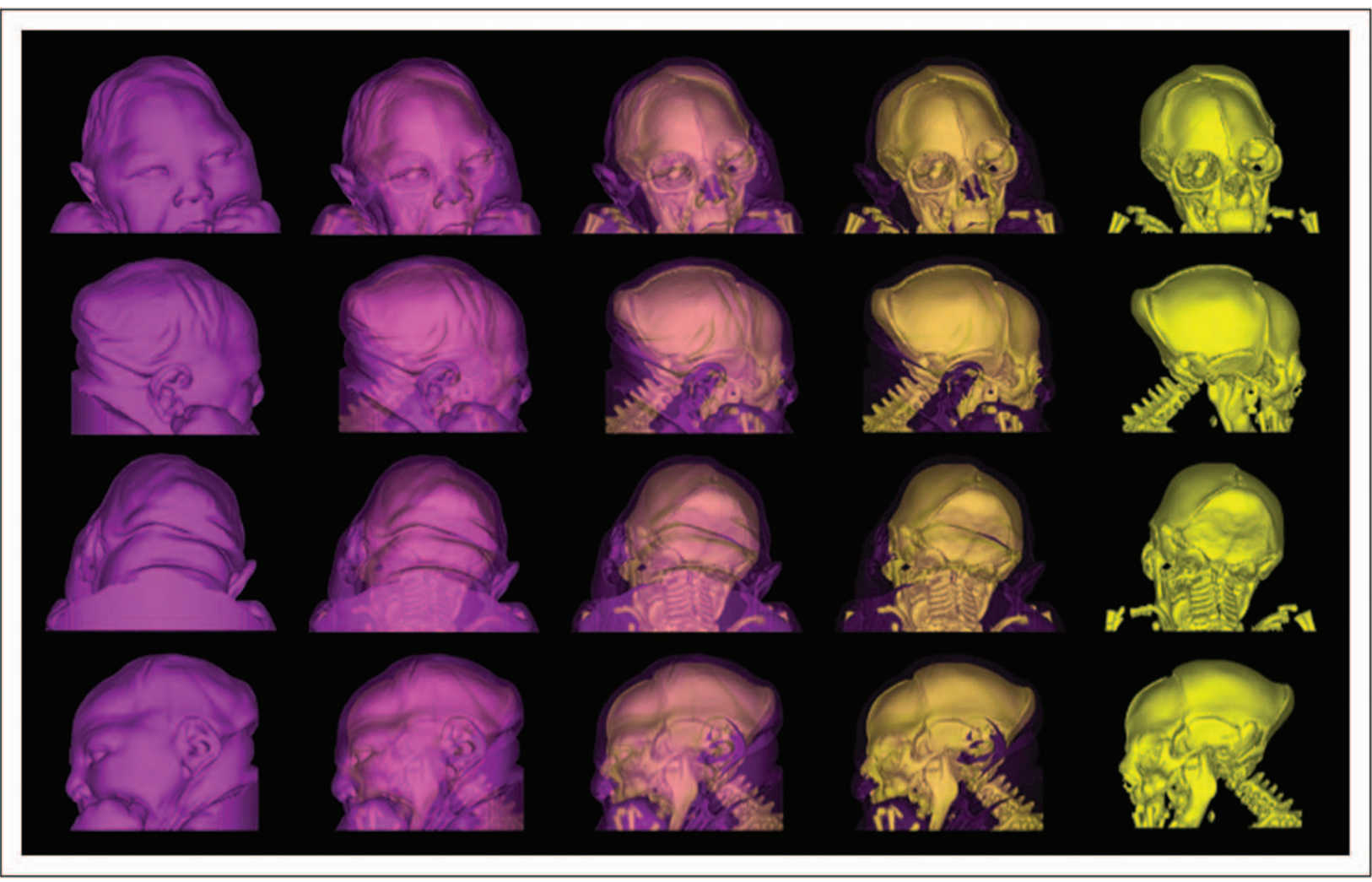

FIGURE 2. Three-dimensional virtual reconstruction from computed tomography of the neonate showing microcephaly. 


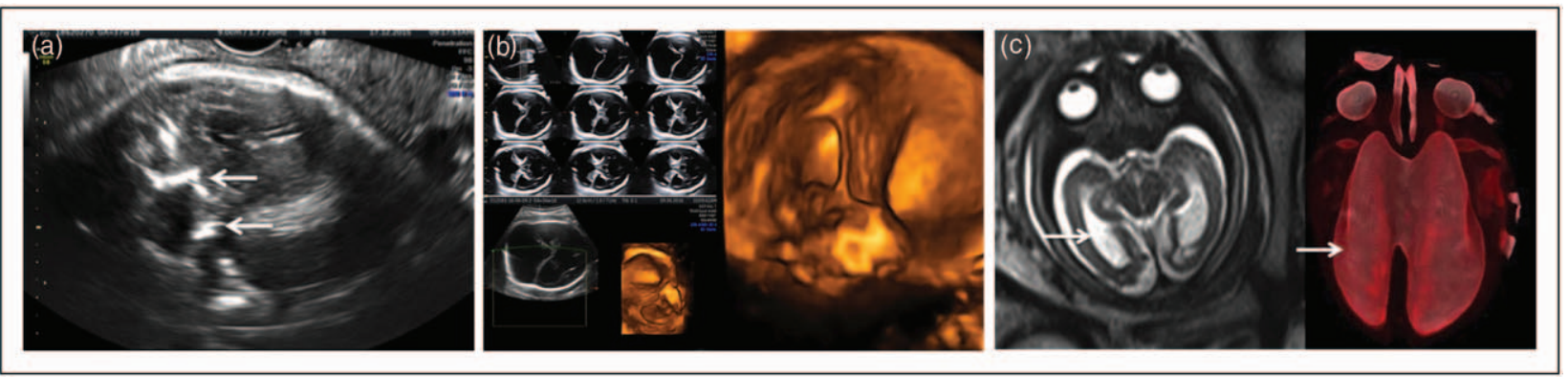

FIGURE 3. (a) Transvaginal ultrasound shows brain calcifications (arrows) and microcephaly in a 37-week fetus. (b) Prenatal ultrasound with three-dimensional reconstruction showing ventricular dilatation in a 34-week fetus positive for Zika virus. (c) Prenatal MRI (axial T2 and three-dimensional reconstruction) showing ventricular dilatation (arrows). Note: limited brain assessment because of the ossified skull artifacts.

[37]. Very recently, Rizzo et al. [38] have demonstrated that with the development of novel threedimensional software, namely five-dimensional CNS, $98.3 \%$ of axial cephalic planes could be successfully reconstructed and all the basic biometric head and brain measurements as well as fetal head volume could be calculated. Moreover, a good interclass correlation with two-dimensional ultrasound was seen $(>0.92)$. Contrary to the observation by Sarris et al. [37], five-dimensional CNS was also able to reduce scanning time [38]. These results are in agreement with those of Tsai et al. [39] that previously demonstrated that a three-dimensional volume analysis algorithm based on the universal facial surface template model containing the geometric shape information of a fetal craniofacial structure, constructed from a fetal phantom, could precisely measure craniofacial structures. Nevertheless, Tonni et al. [40] have shown that cerebral mid-line anomalies, especially those involving the corpus callosum and the cerebellar vermis, can be accurately reformatted using a reslicing technique. One of the main advantages of three-dimensional ultrasound is that all three orthogonal planes can be 'interrogated' and postprocessed offline and sent to experts for consultation using digital communication in medicine (Fig. 3 and Fig. S1, http://links.lww.com/COOG/ A34). f-MRI and postnatal CT scan may be added to two-dimensional-three-dimensional ultrasound to further improve diagnostic accuracy as it allows anatomical images to be obtained with higher resolution of soft tissue contrast (Figs 4 and 5). Moreover, MRI is not influenced as ultrasound is by increased maternal habitus, decreased amniotic fluid or unfavorable fetal positioning. Moreover, f-MRI could improve the diagnostic accuracy of the severity of the brain abnormalities; this technical characteristic correlates well with advancing gestational age $\left[27,32^{*}, 41\right]$.

Neuropathology associated with intrauterine ZIKV infection is characterized by nonspecific findings of brain disorder (diffuse cortical calcification, mid-line echo abnormalities encompassing callosal dysgenesis to cerebellar vermis anomalies, reduced gyration, pachygyria and lissencephaly) that overlaps with those seen in other viral congenital infections. Reduced cortical gyration and white-matter hypomyelination or dysmyelination and cerebellar hypoplasia in the majority of newborns suggest that ZIKV is associated with a disruption in brain development rather than destruction of the brain. Neuronal and glial proliferation as well as neuronal migration appear to be affected [42"].

The contribution of f-MRI to the diagnosis of polymicrogyria, laminar necrosis and brainstem anomalies, compared with ultrasound, is well established [43,44]. Moreover, it may also confirm ultrasound in cases of microcephaly, defined sonographically as head circumference below the third centile and at MRI as cerebral biparietal diameter and fronto-occipital diameters below the third centile [45]. Specifically, f-MRI should describe, better than ultrasound, the following brain characteristics: pachygyria, cerebral ventricular enlargement due to white matter hypoplasia (mainly affecting the posterior aspect of the lateral ventricles), malformations of cortical development and sulcation, corpus callosum dysgenesis (agenesis, hypogenesis and hypoplasia), evaluation of myelination (normal or delayed) according to the stage of development at which changes in myelination appear on T1weighted and T2-weighted images [46,47]. One of the main hallmarks of brain imaging is widespread calcifications in the junction between the cortical and subcortical white matter, abnormal cortical development (pachygyria and polymicrogyria), especially involving the frontal lobe, ventriculomegaly and enlarged cisterna magna, cerebellar and brainstem hypoplasia, moderate and severe lissencephly and delayed myelination. It is noteworthy that the predominance of the frontal lobes for pachygyria and polymicrogyria has not been observed in cases of other congenital infections of the CNS [46]. 


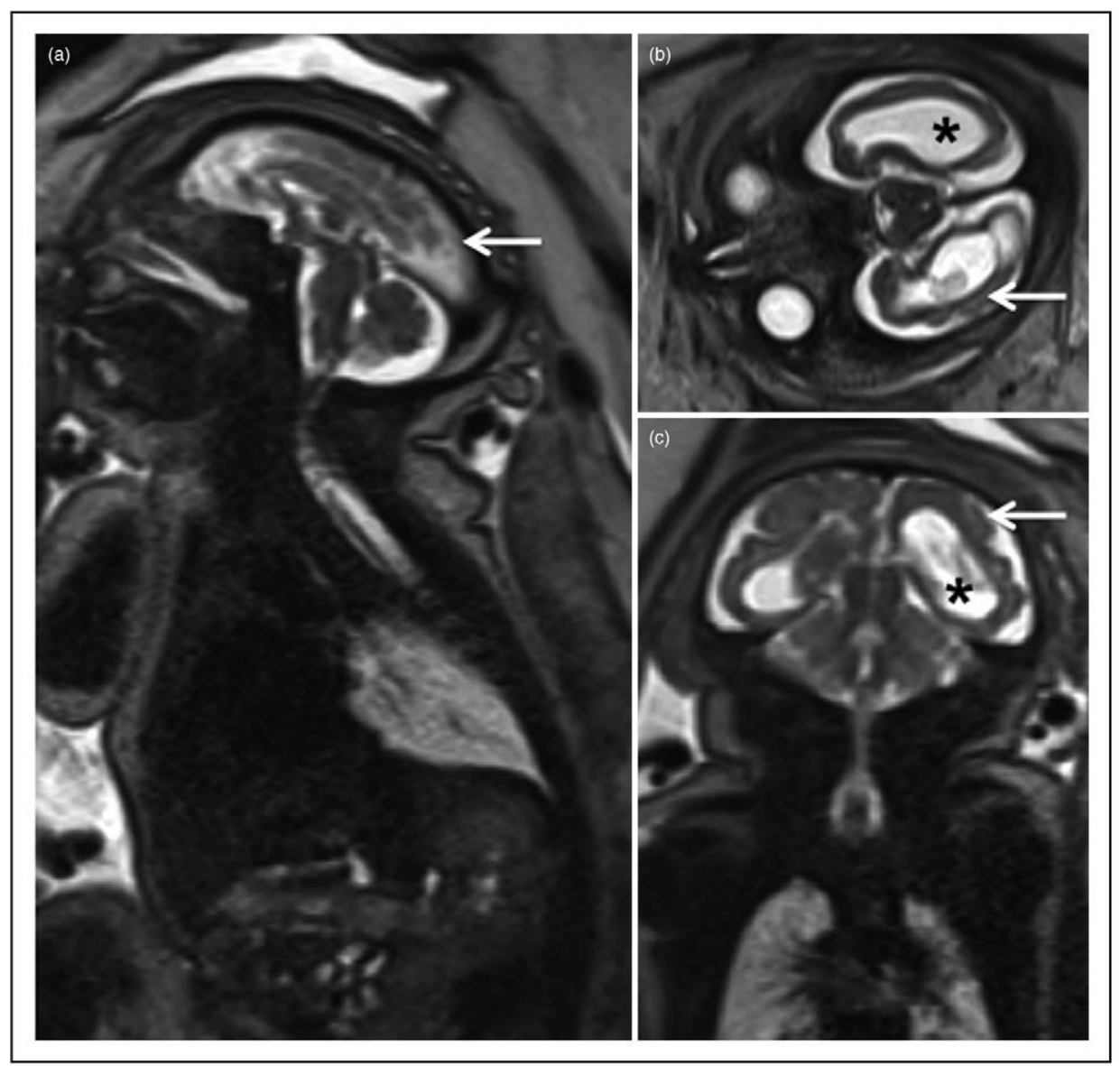

FIGURE 4. T2-weighted MRI of the fetus in sagittal, axial and coronal view at 37 weeks. Note: microcephaly, ventricular dilatation $(*)$, important smoothness of the brain surface and cortical atrophy (arrow).

In addition, enlargement of the supratentorial arachnoid space may cause a severely enlarged head circumference, thereby making a small brain volume [46]. MRI and CT scans offer high sensitivity and specificity for brain disorder (Figs 6 and 7 and Fig. S2, http://links.lww.com/COOG/A34). Nonetheless, the use of three-dimensional volumes generated by MRI and CT alongside additive manufacturing technologies has increased exponentially, producing virtual physical models of congenital anomalies (Fig. S3, http://links.lww.com/ COOG/A34). This novel technology is adopted to assist medical diagnosis, allowing physicians to accurately visualize and define relevant internal and external anatomical details as well as converting the reconstructed anatomy into a set of digital three-dimensional data $[36,41]$.

These files are then converted into threedimensional files with a Standard Triangulation Language (STL) extension, which basically consists of $X, Y$ and $Z$ coordinates. Once the STL file is generated, the next step is the horizontal slicing of the entire three-dimensional volumetric file, using the appropriate software. Thus, the supporting structures will be calculated, if needed (Fig. S4, http://links.lww.com/COOG/A34). The building process starts with the sequential deposition of material layers, which range from microns to fractions of millimeters, depending on the type of technology selected $[48,49]$.

There are currently several systems of additive manufacturing/three-dimensional printing technologies that are commercially available. Although they use different material processes, they are all based on the same principle of physical materialization by layer deposition. Three-dimensional printing may also provide a new didactic approach to learning when applied to modern medicine. Three-dimensional virtual physical models of congenital anomalies obtained from three-dimensional ultrasound, MRI and CT scan data have been used to enhance parents' understanding of several congenital malformations [32',36,41, $48,49]$, especially if parents are blind [50]. It is our belief that three-dimensional virtual physical models could be an imaging repository of the prenatal and postnatal diagnosis of microcephalyassociated ZIKV infection. 

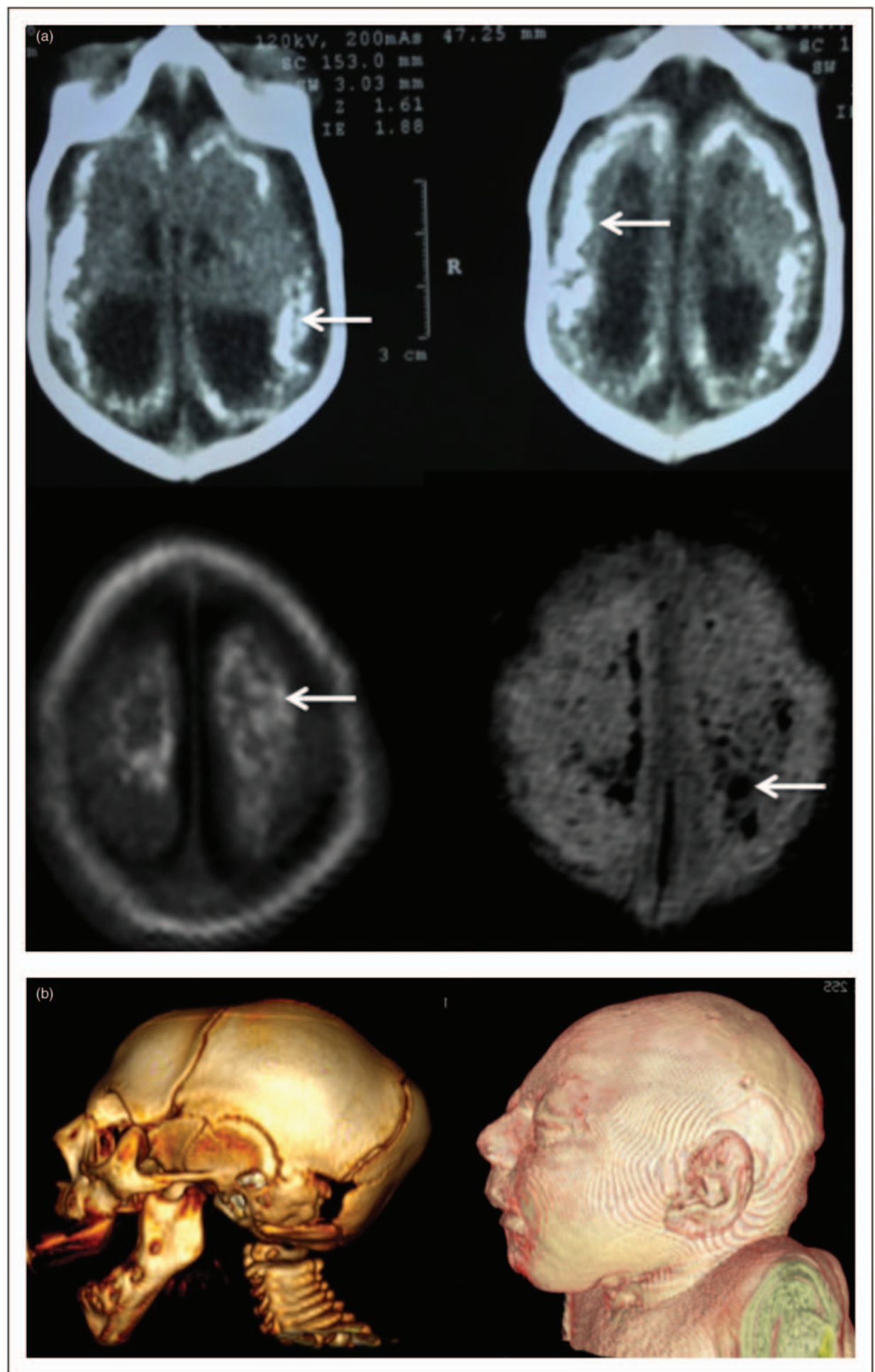

FIGURE 5. (a) Postnatal computed tomography (a1 and a2) and MRI (a3, T1-weighted image and a4, susceptibility-weighted image) showing calcifications (arrows). (b) Three-dimensional reconstruction from postnatal computed tomography and MRI showing marked microcephaly.

\section{CONCLUSION}

The spectrum of microcephaly-associated intrauterine ZIKV infection and multiple brain abnormalities raises important issues when managing a mother with potential congenital ZIKV transmission
(Fig. 7). Prenatal neuroimaging is mainly based on two-dimensional-three-dimensional ultrasound, although f-MRI may be added as complementary diagnostic armamentarium $\left[20^{-}, 21^{*}, 27,32^{\prime \prime}\right]$. The contribution of f-MRI to the diagnosis of 


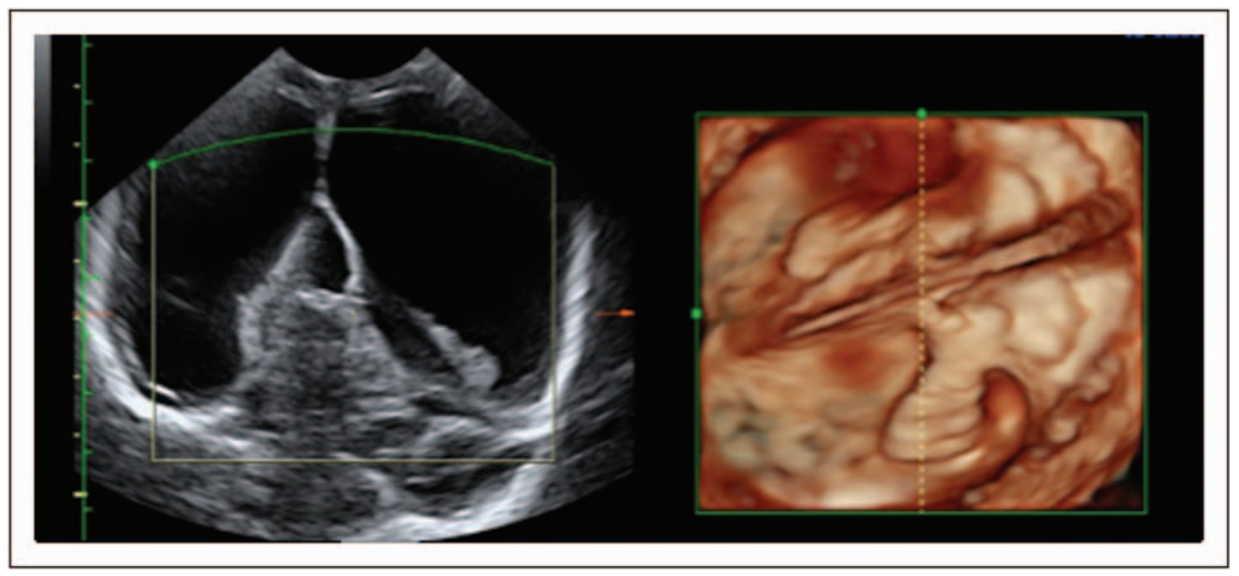

FIGURE 6. Postnatal two-dimensional and three-dimensional transfontanelle ultrasound showing cortical atrophy and ventricular dilatation.

polymicrogyria, laminar necrosis and brainstem anomalies, compared with ultrasound, is well established $[47,48]$. Moreover, f-MRI may be useful to confirm ultrasound findings in case of microcephaly [45]. Brain calcifications, one of the most common neuroimaging features, are seen better with a CT scan rather than MRI $\left[20^{*}, 21^{\prime \prime}, 44,46\right]$; this finding should be taken into consideration in newborns undergoing neuroimaging follow-up. Considering that f-MRI is a costly diagnostic investigation that may not be available at all medical facilities and also considering the fact that fetuses referred for an ultrasound-targeted $\mathrm{f}$ MRI represent a subset of fetuses requiring a thorough MRI neuroimaging investigation, it is mandatory that f-MRI be interpreted by a pediatric neuroradiologist. MRI represents the most sensitive postnatal investigation to assess brain abnormalities, the latter occurring in nearly $76 \%$ of cases of microcephalyassociated intrauterine ZIKV infection. Brain disorders include white matter anomalies (40\%), corpus callosum anomalies (31\%), infratentorial lesions $(15 \%)$ and gyration defects (14\%) [51]. Genetic

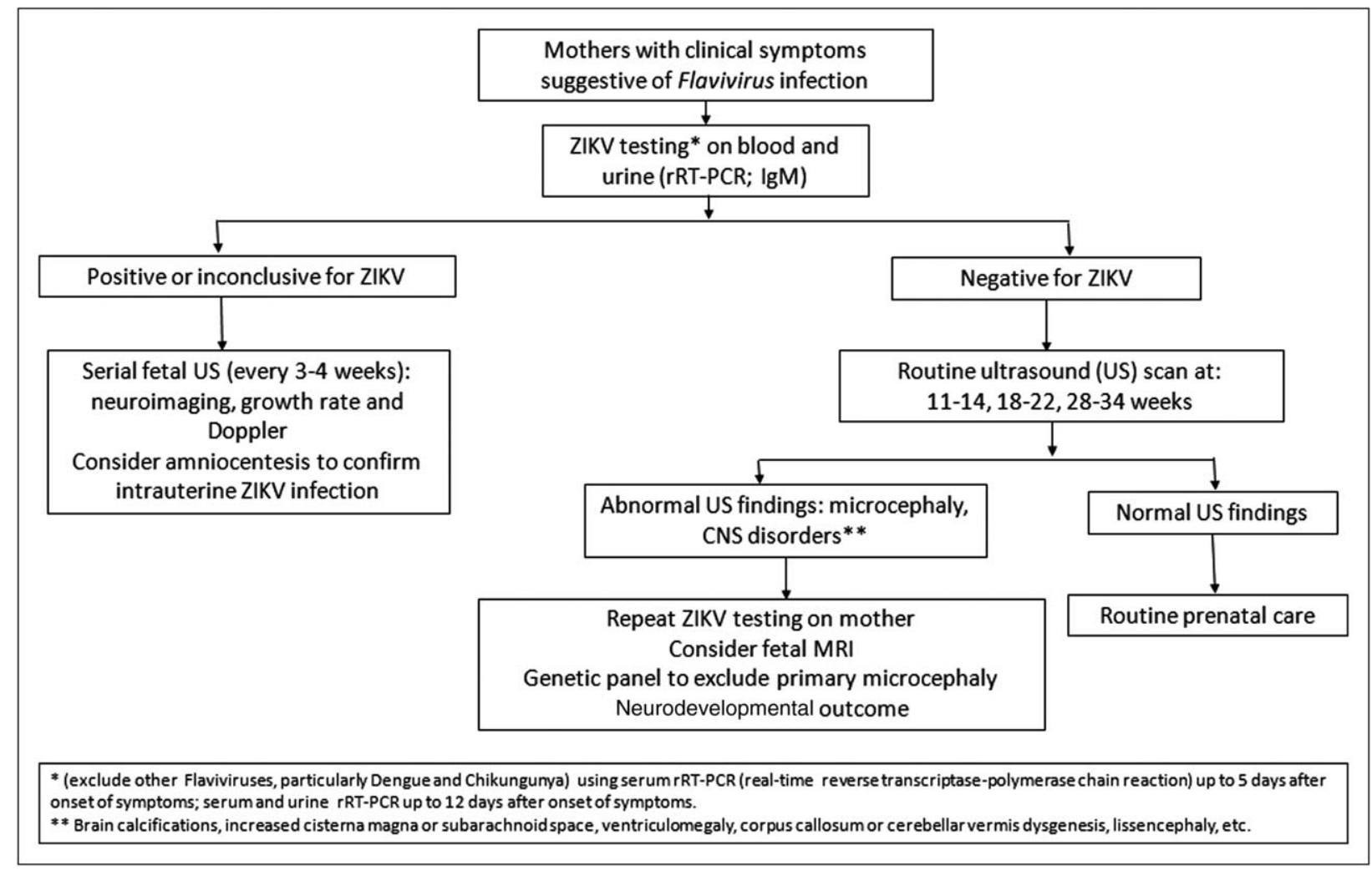

FIGURE 7. Flowchart of the following of mothers with clinical symptoms suggestive of Zika virus intrauterine infection. 
workup aids in distinguishing between primary microcephaly, especially the type associated with simplified gyral pattern and brainstem hypoplasia, from secondary microcephaly to viral infections or Toxoplasmosis. A molecular search should be carried out for mutations in genes involved in the regulation of the developing forebrain and hindbrain like LIS1 or MCPH1 genes [52] or in genes related to neuronal migration and synaptic structural support [calcium/ calmodulin-dependent serine protein kinase (CASK, $\mathrm{X}$-linked)] as well as gene encoding for vesicle membrane transport like RAB3GAP 1 or RAB3GAP2 (Warburg-microcephaly, autosomal dominant) [53]. The genetic panel should be considered ancillary to diagnostic investigation and performed in all cases of antenatally detected microcephaly with associated brain disorder. The disease might not be microcephaly-associated intrauterine ZIKV infection but perhaps a novel syndrome characterized by a wide phenotype in which microcephaly with associated brain disorder may reflect a severe form or end-stage of the clinical spectrum of congenital ZIKV infection. We do agree with Sàfadi's statement that 'the true burden of the congenital disease associated with ZIKV infection is underestimated' [54]. In summary, the following considerations could be drawn: prenatal neuroimaging is based on two-dimensional-threedimensional ultrasound; f-MRI may enhance the sensitivity of the antenatal detection of brain abnormalities associated with ZIKV intrauterine infection; genetic workup to exclude primary microcephaly should be carried out and postnatal follow-up in newborns with pathologic neuroimaging should be based on MRI and CT. Future therapeutic options and development of vaccines $[55,56]$ might be the possible scenario for this severe viral congenital infection.

\section{Acknowledgements}

We would like to thank Dr Andrea Rossi and Dr Ana Sofia Cruz for their assistance with the study.

\section{Financial support and sponsorship}

None.

\section{Conflicts of interest}

There are no conflicts of interest.

\section{REFERENCES AND RECOMMENDED}

\section{READING}

Papers of particular interest, published within the annual period of review, have been highlighted as:

- of special interest

-1. of outstanding interest

1. Duffy MR, Chen TH, Hancock WT, et al. Zika virus outbreak on Yap Island, Federated States of Micronesia. N Engl J Med 2009; 360:25362543.
2. Diagne CT, Diallo D, Faye O, et al. Potential of selected Senegalese Aedes spp. mosquitoes (Diptera: Culicidae) to transmit Zika virus. BMC Infect Dis 2015; 15:492.

3. Grard G, Caron M, Mombo IM, et al. Zika virus in Gabon (Central Africa) - 2007: a new threat from Aedes albopictus? PLoS Negl Trop Dis 2014; 8:e2681.

4. Wong PS, Li M, Chong C, et al. Aedes (Stegomyia) albopictus (Skuse): a potential vector of Zika virus in Singapore. PLoS Negl Trop Dis 2013; $7: e 2348$.

5. Diallo D, Sall A, Diagne C, et al. Zika virus emergence in mosquitoes in Southeastern Senegal, 2011. PLoS One 2014; 9:e109442.

6. Paixão ES, Barreto F, Teixeira MG, et al. History, epidemiology, and clinical manifestations of Zika: a systematic review. Am J Public Health 2016; 106:606-612.

7. Boeuf $P$, Drummer HE, Richards JS, et al. The global threat of Zika virus to pregnancy: epidemiology, clinical perspectives, mechanisms, and impact. BMC Med 2016; 14:112.

8. Tognarelli J, Ulloa S, Villagra E, et al. A report on the outbreak of Zika virus on Easter Island, South Pacific, 2014. Arch Virol 2016; 161:665-668.

9. Zanluca C, Melo V, Mosimann A, et al. First report of autochthonous transmission of Zika virus in Brazil. Mem Inst Oswaldo Cruz 2015; 110:569-572.

10. Campos GS, Bandeira A, Sardi S. Zika virus outbreak, Bahia, Brazil. Emerg Infect Dis 2015; 21:1885-1886.

11. Faria NR, da Silva Azevedo RS, Kraemer MUG, et al. Zika virus in the

- Americas: early epidemiological and genetic findings. Science 2016; 352:345-349.

This manuscript used a phylogenetic molecular approach to investigate the molecular epidemiology of Zika virus (ZIKV) in the Americas.

12. Ministry of Health of Brazil, Secretary of Health of the State of Bahia. Epidemiological situation of arboviruses. Bull Epidemiol 2015; 11.

13. Silva MM, Rodrigues MS, Paploski IA, et al. Accuracy of dengue reporting by national surveillance system, Brazil. Emerg Infect Dis 2016; 22:336-339.

14. Ministério da Saúde do Brasil. Boletim Epidemiológico 47:7: Semana epidemiológica (SE) 04. Secretaria de Vigilância em Saúde; 2016 ; Available from: http://portalsaude.saude.gov.br/index.php/situacao-epidemiologicadados-dengue. [Accessed 30 January 2016; in Portuguese]

15. Lindenbach BD, Rice CM. Molecular biology of flaviviruses. Adv Virus Res 2003; 59:23-61.

16. Adibi JJ, Marques ET Jr, Cartus A, Beigi RH. Teratogenic effects of the Zika

n. virus and the role of the placenta. Lancet 2016;387:1587-1590.

This manuscript theorizes the pathogenetic mechanisms of the placenta causing brain defects.

17. Montiel JF, Kaune $H$, Maliqueo M. Maternal-fetal unit interactions and eutherian neocortical development and evolution. Front Neuroanat 2013; 7:22.

18. Adibi JJ, Zhao $Y$, Cartus AR, et al. Placental mechanics in the Zika-micro-

- cephaly relationship. Cell Host Microbe 2016; 20:9-11.

Pathogenetic mechanisms of intrauterine ZIKV infection.

19. Calvet G, Aguiar RS, Melo AS, et al. Detection and sequencing of Zika virus

- from amniotic fluid of fetuses with microcephaly in Brazil: a case study. Lancet Infect Dis 2016; 16:653-660.

Genetic detection of ZIKV in amniotic fluid.

20. Carvalho $\mathrm{FH}$, Cordeiro KM, Peixoto $A B$, et al. Associated ultrasonographic

- findings in fetuses with microcephaly because of suspected Zika virus (ZIKV) infection during pregnancy. Prenat Diagn 2016; 36:882-887.

Detection of associated fetal malformations.

21. Oliveira Melo AS, Malinger $G$, Ximenes $R$, et al. Zika virus intrauterine infection

- causes fetal brain abnormality and microcephaly: tip of the iceberg? Ultrasound Obstet Gynecol 2016; 47:6-7.

First prenatal detection of microcephaly in third trimester of pregnancy associated with ZIKV infection.

22. Martines RB, Bhatnagar J, Keating MK, et al. Notes from the field: evidence of

- Zika virus infection in brain and placental tissues from two congenitally infected newborns and two fetal losses - Brazil, 2015. MMWR Morb Mortal Wkly Rep 2016; 65:159-160.

Evidence of a correlation between intrauterine ZIKV infection and disorder.

23. Rubin EJ, Greene MF, Baden LR. Zika virus and microcephaly. N Engl J Med

2016; 374:984-985.

Association between ZIKV infection and microcephaly.

24. Mlakar J, Korva M, Tul N, et al. Zika virus associated with microcephaly. N Engl

n. J Med 2016; 374:951-958.

First isolation of ZIKV RNA in brain tissue.

25. Schuler-Faccini L, Ribeiro EM, Feitosa IM, et al. Possible association between

- Zika virus infection and microcephaly - Brazil, 2015. MMWR Morb Mortal Wkly Rep 2016; 65:59-62.

Insight of etiologic factors of brain disorder in ZIKV infection.

26. Hughes BW, Addanki KC, Sriskanda AN, et al. Infectivity of immature neurons to

- Zika virus: a link to congenital Zika syndrome. EBioMedicine 2016; 10:65-70.

Demonstrated that undifferentiated neurons of the fetus are highly vulnerable to

ZIKV infection, especially before 17 weeks' gestation.

27. Brasil P, Pereira JP Jr, Raja Gabaglia C, et al. Zika virus infection in pregnant women in Rio de Janeiro - preliminary report. N Engl J Med 2016; 375:2321-2334.

28. Cauchemez $S$, Besnard $M$, Bompard $P$, et al. Association between Zika virus and microcephaly in French Polynesia, 2013-15: a retrospective study. Lancet 2016; 387:2125-2132. 
29. Melo AS, Aguiar RS, Amorim MM, et al. Congenital Zika virus infection: beyond neonatal microcephaly. JAMA Neurol 2016; 73:1407-1416.

30. Sarno M, Aquino M, Pimentel K, et al. Progressive lesions of central nervous system in microcephalic fetuses with suspected congenital Zika virus syndrome. Ultrasound Obstet Gynecol 2016. [Epub ahead of print]

31. Werner $H$, Sodré $D$, Hygino $C$, et al. First-trimester intrauterine Zika virus

- infection and brain pathology: prenatal and postnatal neuroimaging findings. Prenat Diagn 2016; 36:1-5.

Neuropathology with antenatal and postnatal imaging.

32. Werner $H$, Fazecas $T$, Guedes $B$, et al. Intrauterine Zika virus infection and

- microcephaly: correlation of perinatal imaging and three-dimensional virtual physical models. Ultrasound Obstet Gynecol 2016; 47:657-660.

First description of three-dimensional virtual models of ZIKV infection-associated microcephaly.

33. Driggers RW, Ho CY, Korhonen EM, et al. Zika virus infection with prolonged

- maternal viremia and fetal abnormalities. N Engl J Med 2016; 374:21422151.

Demonstration that although ZIKV RNA may be found in different fetal organs and the placenta, the virus can be isolated only from brain tissue.

34. Moron AF, Cavalheiro $\mathrm{S}$, Milani $\mathrm{H}$, et al. Microcephaly associated with maternal Zika virus infection. BJOG 2016; 123:1265-1269.

35. Cassart M, Massez $A$, Cos $T$, et al. Contribution of three-dimensional computed tomography in the assessment of fetal skeletal dysplasia. Ultrasound Obstet Gynecol 2007; 29:537-543.

36. Werner H, Lopes Dos Santos JR, Ribeiro G, et al. Combination of ultrasound, magnetic resonance imaging and virtual reality technologies to generate immersive fetal 3D visualizations during pregnancy for fetal medicine studies. Ultrasound Obstet Gynecol 2016. [Epub ahead of print]

37. Sarris I, Ohuma E, loannou $C$, et al. Fetal biometry: how well can offline measurements from three-dimensional volumes substitute real-time two-dimensional measurements? Ultrasound Obstet Gynecol 2013; 42:560-570.

38. Rizzo G, Aiello E, Pietrolucci ME, et al. The feasibility of using 5D CNS software in obtaining standard fetal head measurements from volumes acquired by three-dimensional ultrasonography: comparison with two-dimensional ultrasound. J Matern Fetal Neonatal Med 2016; 29:2217-2222.

39. Tsai $\mathrm{PY}$, Chen $\mathrm{HC}$, Huang $\mathrm{HH}$, et al. A new automatic algorithm to extract craniofacial measurements from fetal three-dimensional volumes. Ultrasound Obstet Gynecol 2012; 39:642-647.

40. Tonni G, Grisolia G, Sepulveda W. Second trimester fetal neurosonography: reconstructing cerebral midline anatomy and anomalies using a novel threedimensional ultrasound technique. Prenat Diagn 2014; 34:75-83.

41. Werner $\mathrm{H}$, dos Santos $J \mathrm{R}$, Fontes $\mathrm{R}$, et al. Additive manufacturing models of fetuses built from three-dimensional ultrasound, magnetic resonance imaging and computed tomography scan data. Ultrasound Obstet Gynecol 2010; 36:355-361.
42. Hazin AN, Poretti A, Turchi Martelli CM, et al. Computed tomographic findings

- in microcephaly associated with Zika virus. N Engl J Med 2016; 374:193195.

Description of neuroradiographic findings in ZIKV infection-associated microcephaly.

43. Blondiaux E, Garel C. Fetal cerebral imaging - ultrasound vs. MRI: an update. Acta Radiol 2013; 54:1046-1054.

44. Guillemette-Artur $P$, Besnard $M$, Eyrolle-Guignot $D$. Prenatal brain MRI of fetuses with Zika virus infection. Pediatr Radiol 2016; 46:1032-1039.

45. Tilea $B$, Alberti $C$, Adamsbaum $C$, et al. Cerebral biometry in fetal magnetic resonance imaging: new reference data. Ultrasound Obstet Gynecol 2009; 33:173-181.

46. de Fatima Vasco Aragao M, van der Linden V, Brainer-Lima AM, et al. Clinical features and neuroimaging (CT and MRI) findings in presumed Zika virus related congenital infection and microcephaly: retrospective case series study. BMJ 2016; 353:11901.

47. Dreha-Kulaczewski SF, Brockmann K, Henneke M, et al. Assessment of myelination in hypomyelinating disorders by quantitative MRI. J Magn Reson Imaging 2012; 36:1329-1338.

48. Werner H, Lopes J, Tonni G, Araujo Júnior E. Physical model from 3D ultrasound and magnetic resonance imaging scan data reconstruction of lumbosacral myelomeningocele in a fetus with Chiari II malformation. Childs Nerv Syst 2015; 31:511-513.

49. Werner H, Rolo LC, Araujo Júnior E, Dos Santos JR. Manufacturing models of fetal malformations built from 3-dimensional ultrasound, magnetic resonance imaging, and computed tomography scan data. Ultrasound Q 2014; 30: 69-75.

50. Werner H, Lopes J, Tonni G, Araujo Júnior E. Maternal-fetal attachment in blind women using physical model from three-dimensional ultrasound and magnetic resonance scan data: six serious cases. J Matern Fetal Neonatal Med 2016; 29:2229-2232.

51. Soares de Oliveira-Szejnfeld $P$, Levine $D$, Melo AS, et al. Congenital brain abnormalities and Zika virus: what the radiologist can expect to see prenatally and postnatally. Radiology 2016; 282:203-218.

52. Rajab A, Manzini MC, Mochida GH, et al. A novel form of lethal microcephaly with simplified gyral pattern and brain stem hypoplasia. Am J Med Genet 2007; 143A:2761-2767.

53. Seltzer EL, Paciorkowski AR. Genetic disorders associated with postnatal microcephaly. Am J Med Genet C Semin Med Genet 2014; 166C:140-155.

54. Sàfadi MA. Zika virus: what have we learned? Am J Perinatol 2016; 33:10291031.

55. Marston HD, Lurie N, Borio LL, Fauci AS. Considerations for developing a Zika virus vaccine. N Engl J Med 2016; 375:1209-1212.

56. Thomas $S J$, L'Azou M, Barrett $A D$, et al. Fast-track Zika vaccine development - is it possible? N Engl J Med 2016; 375:1212-1216. 